$\left(\begin{array}{ccc}\text { Jpn. J. Hosp. Pharm } \\ \text { He } \\ 261 & 13-16(2000))\end{array}\right)$

\title{
ヒドロキシジン急性薬物中毒患者における血中濃度と中毒症状や
}

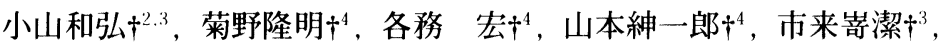

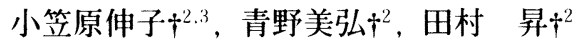 \\ 国立病院東京医療センター臨床研究部†2 \\ 国立病院東京医療センター薬夙科 +3 \\ 国立病院東京医療センター救命救急センター
}

\section{Serum Hydroxyzine Concentrations and Toxic Symptom in Acute Intoxication Patients $\dagger^{1}$}

\author{
KAZUHIRO KOYAMA $\dagger^{2.3}$, TAKAAKI KIKUNO $\dagger^{4}$, HIROSHI KAGAMI $\dagger^{4}$, \\ SHIN-ICHIRO YAMAMOTO $\dagger^{4}$, KIYOSHI ICHIKIZAKI $\dagger^{3}$, NOBUKO OGASAWARA $\dagger^{2,3}$, \\ YOSHIHIRO AONO $\dagger^{2}$ and NOBORU TAMURA $\dagger^{2}$ \\ Institute for Clinical Research $\dagger^{2}$. \\ Department of Pharmacy $\dagger^{3}$,
}

Emergency and Critical Care Unit $t^{4}$, National Tokyo Medical Center

$\left(\begin{array}{l}\text { Received March 30, } 1999 \\ \text { Accepted September 20, 1999 }\end{array}\right)$

The serum drug concentrations in 6 cases of acute hydroxyzine intoxication patients were measured by HPLC. The patients were admitted about $1-10$ hours after ingesting from 200 to $15000 \mathrm{mg}$ hydroxyzine. The serum hydroxyzine levels were within a range of $0.12-1.70 \mu \mathrm{g} /$ $\mathrm{mL}$. The elimination half-lives were within a range of $4.7-111$ hours during treating the patients by forced diuresis. The serum hydroxyzine levels associated with drowsiness was $>0.51 \mu$ $\mathrm{g} / \mathrm{mL}$, while that associated with vomiting was $>0.51 \mu \mathrm{g} / \mathrm{mL}$ and that with is miosis was $>$ $1.40 \mu \mathrm{g} / \mathrm{mL}$. Only one fetal case was encountered. However, the fetal case could possibly have been due to trazodone rather than hydroxyzine because the concentration of hydroxyzine was $0.12 \mu \mathrm{g} / \mathrm{mL}$.

Key words - hydroxyzine, intoxication, poisoning, TDM, vomiting, miosis

\section{緒言}

パモ酸ヒドロキシジンは抗ヒスタミン作用をも

$\ddagger^{1}$ 本報の要旨は、第 8 回日本病院薬学会(1998年9月, 横浜)で発表.

$†^{2-4}$ 東京都目黒区東が 丘.2-5-1；2-5-1, Higashigaoka, Meguro-ku, Tokyo, 152-8902 Japan
つ薬剤で，抗アレルギー性精神安定剤として抗ア レルギー剤としてだけでなく静榣鎮静剤として多 く使用される薬郕である。また，医療用だけでな く一般の楽局でも処方せんなしに販売されてお り，比較的手軽に，多量に入手することが可能な 薬鼡でもある。

このパモ酸ヒドロキシジンが一部の自殺マニュ 
アル1)等で自殺が可能な薬剛として紹介され，そ のための服用量として 600 錠（ 1 錠 $=25 \mathrm{mg}$ ）が目 安として示された。その影響のため実際に自殺目 的でパモ酸ヒドロキシジンを 600 錠前後もの多量 を服用する患者が現れるようになるなど社会問題 となっている，今回，パモ酸ヒドロキシジンを自 殺目的のために多量服用した患者の血中濃度と症 状との関係を調べた。

\section{対象および方法}

対象は1995年 1 月〜 1997年12月の 2 年間にパモ 酸ヒドロキシジンを服用し急性薬物中毒で入院し た 6 例に対して血清中濃度の測定を行った。な お，測定方法は既報 ${ }^{2)}$ に従い高速液体クロマト グラフィー（以下 HPLC）にて行った。また，す べての症例において胃洗浄, 強制利尿, 腸洗浄 （ニフレック®と活性炭の投与）を行った。

\section{結果}

服用錠数は 8 錠〜 600錠（200〜15000mg）を服 用しており, 服用から病院へ入院する間の時間は $1 \sim 10$ 時間, 血清中濃度は $0.12-1.70 \mu \mathrm{g} / \mathrm{mL}$ の 濃度であった（Table 1)。パモ酸ヒドロキシジ ン単独と考えられる 4 症例において, 血清ヒドロ キシジン濃度が $0.26 \mu \mathrm{g} / \mathrm{mL}$ の症例 3 においては 症状は見られず, $0.51 \mu \mathrm{g} / \mathrm{mL}$ 以上の症例 1 , 2,4 で軽度の意識レベルの低下と嘔吐が見ら れ， $1.48 \mu \mathrm{g} / \mathrm{mL}$ 以上の症例 $1 ， 2$ で軽度の縮曈 が見られた (Fig. 1). 死亡した症例 6 以外は特 にパモ酸ヒドロキシジンと考えられる重篤な症状 は見られず，翌日までにほとんどの症状は消失し 回復した.また, 血清中からのみかけの消失半減 期（強制利尿下）は4.7-111hrの值であった (Fig. 2).

Table 1. Serum Drug Concentration and Toxic Symptom in Hydroxyzine and Other Drugs Intoxication Patients

\begin{tabular}{|c|c|c|c|c|c|c|c|c|}
\hline NO. & Sex & Age & $\begin{array}{l}\text { Time after } \\
\text { last admin. } \\
\quad(\mathrm{hr})\end{array}$ & Drug & $\begin{array}{l}\text { Dose } \\
(\mathrm{mg})\end{array}$ & $\begin{array}{c}\text { Concentration } \\
(\mu \mathrm{g} / \mathrm{mL})\end{array}$ & $\begin{array}{l}\text { Coma } \\
\text { scale } \\
\text { (JCS) }\end{array}$ & $\begin{array}{l}\text { Clinical } \\
\text { condition }\end{array}$ \\
\hline 1 & M & 19 & 8 & hydroxyzine & 5000 & 1.70 & 10 & Vomiting, Miosis \\
\hline 2 & $\mathrm{~F}$ & 25 & 1.5 & hydroxyzine & 15000 & 1.48 & 1 & Vomiting, Miosis \\
\hline 3 & $\mathrm{~F}$ & 25 & $?$ & hydroxyzine & 500 & 0.26 & 0 & Normal \\
\hline \multirow[t]{2}{*}{4} & $\mathrm{~F}$ & 27 & 10 & hydroxyzine & 15000 & 0.51 & 10 & Vomiting \\
\hline & & & & Alcohol & $?$ & 990 & & \\
\hline \multirow[t]{4}{*}{5} & $\mathrm{~F}$ & 20 & 6 & hydroxyzine & $?$ & 0.75 & 30 & \\
\hline & & & & Amobarbital & $?$ & 1.34 & & \\
\hline & & & & Brotizolam & $?$ & 0.053 & & \\
\hline & & & & Etizolam & $?$ & 0.742 & & \\
\hline \multirow[t]{7}{*}{6} & $\mathrm{~F}$ & 34 & 1 & hydroxyzine & 200 & 0.12 & & Death \\
\hline & & & & Clonazepam & $?$ & 14.472 & & \\
\hline & & & & Brotizolam & 8.5 & 0.154 & & \\
\hline & & & & Trazodone & 1050 & 275.97 & & \\
\hline & & & & Haloperidol & $?$ & 0.053 & & \\
\hline & & & & Amitriptyline & 400 & 0.269 & & \\
\hline & & & & Anafranil & 50 & 0.225 & & \\
\hline
\end{tabular}




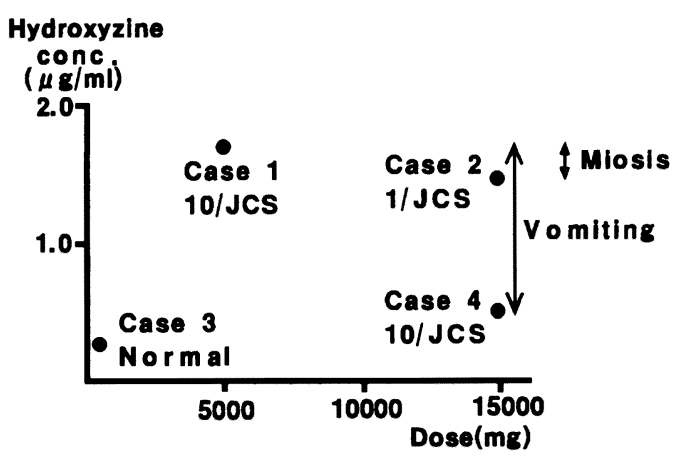

Fig. 1. Serum Concentration and Clinical Condition of Hydroxyzine Intoxication Patients (Case 1 4) JCS : Japan Coma Scale

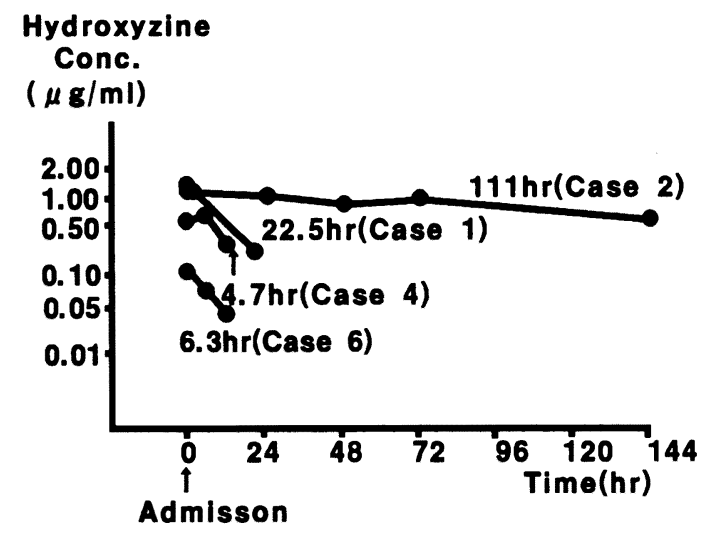

Fig. 2. Elimination Half-life on Hydroxyzine Intoxication Patients

\section{考察}

ヒドロキシジンによる毒性については死亡例が 2 例報告されており，Johnson ${ }^{3)}$ による43歳女性 において死後の測定であるが血中濃度が $39 \mu \mathrm{g} /$ $\mathrm{mL}$ の例, Spiehler ら ${ }^{4)}$ による46歳女性において死 後の測定で血中濃度が $1.1 \mu \mathrm{g} / \mathrm{mL}$ であった例等が 報告されている。重症例としては Magera $ら^{5)} に$ よる13月齢で体重 $11 \mathrm{~kg}$ の小児において20～25錠 $(0.5 \sim 0.625 \mathrm{~g})$ 服用し8.5時間後の血中濃度が $102.7 \mu \mathrm{g} / \mathrm{mL}$, 痤攣, 頻脈, 散瞳, 間欠的な無呼

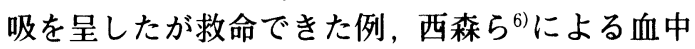

濃度は不明だが21歳女性でアタラックス $\mathrm{P}^{\circledR} 210$ 錠 $(5.25 \mathrm{~g})$ 服用し, 意識レベルの低下，縮瞳，痤 攣をおこしたが，その後回復した例等が報告され ている，一方で，ヒドロキシジンとしてヒト推定 致死量は25- $250 \mathrm{mg} / \mathrm{kg}$, 最大耐性量は成人で 1 〜 $\mathrm{g}$ （傾眠，昏睡状態を起こしたが後遺症なく 回復）とされている7).

今回の症例では，例えば200錠服用で $5 \mathrm{~g}, 600$ 錠で15g ものヒドロキシジンを服用したことにな り，特に600錠服用した症例ではヒト推定致死量 と最大耐性量も超して服用している。それに対し て症例 6 以外は, 症状として意識障害, 嘔吐, 縮 瞳とそれほど重症な症状は出現しなかった。

Fig. 1 の血清中濃度から見ると服用量により血清 中濃度が増加している傾向はなく，これはヒドロ キシジンの中毒症状として多く出ている嘔吐 $(\mathrm{Ta}-$ ble 1 ）により，服用薬物が体内に吸収される前 にある程度排出されたことと関係があると考えら れる，ただ，血清中濃度が上昇するに従い嘔吐， 縮瞳と次第に中枢に対する中毒症状が強く出てく る傾向が見られることより，おそらく今回の症例 の血清中濃度以上に上昇すると痤覓手，さらには呼 吸抑制などを起こし致死的になる可能性があるの ではないだろうか.

症例 6（Table 1 ）は死亡例である。ヒドロキ

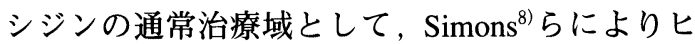
ドロキシジンの経口単回投与 $(0.7 \mathrm{mg} / \mathrm{kg})$ にお いて約2.1時間後のピーク血中濃度が $0.0725 \pm$ $0.0111 \mu \mathrm{g} / \mathrm{mL}$ ，半減期が $20.0 \pm 4.1$ 時間と報告さ れている. 症例 6 のヒドロキシジンの血清中濃度 は0.12 $\mu \mathrm{g} / \mathrm{mL}$ と通常治療域よりは高めであるが 無症状であった症例 3 の $0.26 \mu \mathrm{g} / \mathrm{mL} よ り$ 低く， 逆に併用していた薬物のトラゾドンによる死亡例 が死後の血中濃度であるが, $9.69 \mu \mathrm{g} / \mathrm{mL}^{9)}$ および $14.4 \mu \mathrm{g} / \mathrm{mL}, 15.5 \mu \mathrm{g} / \mathrm{mL}^{10)}$ と報告されており， ヒドロキシジンによるものではなくトラゾドンに よる死亡例と考えられる.

症例 5 (Table 1 ) は他の症例より意識レベル の低下が Japan coma scale（以下 JCS）で30と強 
く出ている，確かにヒドロキシジン自体の血清中 濃度も比較的高いが, さらに高い症例（症例

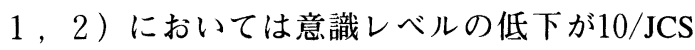
止まりである。それに対して，併用されていたブ ロチゾラムは睡眠凨であるが，Bechtel ${ }^{11)}$ によれ ば $0.5 \mathrm{mg}$ 単回投与でピーク血中濃度は $0.0047-$ $0.0068 \mu \mathrm{g} / \mathrm{mL}$ とされており，おそらく睡眠㓮と しての有効血中濃度にあったと考えられ，この意 識レベルの低下はヒドロキシジンではなくブロチ ゾラムの作用によると思われる.

ヒドロキシジンの通常治療域における半減期は $20.0 \pm 4.1$ 時間と報告 $^{8)}$ されているが, それと比 較して Fig. 2の見かけの半減期の值は4.7〜111

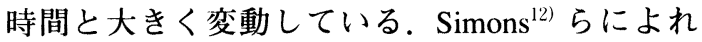
ば小児（6.1士4.6歳）においてヒドロキシジンの 半減期は7.1 12.3 時間と大人と比較して有意に低 下していたとの報告があるが，今回の年齢は19 34歳 (Table 1) とすべて大人と考えてよく, おそ らく半減期の短い症例は中毒に対する処置である 強制利尿などが有効に作用して消失が速くなった と考えられる，さらに，血中濃度が高くなるに従 い半減期が長くなる傾向が見られるが, Close ${ }^{13)} ら$ によるとラットにおいて $50 \mathrm{mg} / \mathrm{kg}$ 以上で肝代謝 の飽和現象が見られるとの報告があり，おそらく それと同様に人間においても肝代謝の飽和現象が
現れ半減期の延長がおきた可能性が考えられる.

\section{引用文献}

1) 鶴見済、“完全自殺マニュアル”，18版，太田出 版, 東京, 1993, pp.22.

2) 小山和弘, 菊野隆明, 市来崇潔, 村越功治, 城 川裕美，不井漱一。病院薬学，22, 45-51 (1996).

3) G.R.Johnson, J.Anal.Toxicol ., 6, 69-70 (1982).

4) V.R. Spiehler and R.I. Fukumoto, J. Anal. Toxicol., 8, 242-243 (1984).

5) B.E.Magera, C.J.Betlach, A.P.Sweatt and C. W.Derrick, Pediatrics, 67, 280-283 (1981).

6) 西森茂樹, 山本博俊, 杉田学, 繁田正毅、三宅 健史，双本折也，日救急矤会関東誌，17，62-63 (1996).

7) 後滕京子, 辻川明子, 中毒研究, 8, 265-270 (1995).

8) F.E.R.Simons, K.J.Simons and E.M.Frith, J. Allergy Clin. Immunol ., 73, 69-75 (1984).

9) I. Root and G.B. Ohlson, J. Anal. Toxicol ., 8. 91-94 (1984).

10) A. Martin and D.J. Pounder, Forensic Sci. Int., 201-207 (1992).

11) W.D. Bechtel, Br. J. Clin.Pharmacol ., 16, 279 S-283 S (1983).

12) F.E.R. Simons, K.J. Simons, A.B. Becker and R.P. Haydey, J. Pediatr., 104, 123-127 (1984).

13) J.A. Close, J.G. Gobert and L.A.M.Rodriguez, Int. Congr. Ser., 145, 144-155 (1968) . 